\title{
Ranking critical success factor in chaos management using BSC and AHP method
}

\author{
Ehsan Khosravi Asil $^{a^{*}}$, Alireza Shahraki ${ }^{b}$ and Keyvan Shahgholian ${ }^{a}$
}

${ }^{a}$ Department of Industrial Engineering, Zahedan Branch, Islamic Azad University, Zahedan, Iran

${ }^{b}$ Department of Industrial Engineering, University of Sistan and Baluchestan, Zahedan, Iran

CHRONICLE ABSTRACT

Article history:

Received January 18, 2013

Received in revised format

10 May 2013

Accepted May 152013

Available online

May 162013

Keywords:

Chaos management

Analytical hierarchy process

Balanced Scorecard

\begin{abstract}
Managing an organization under chaos and uncertainty is often a concern of academic society. These days, we may face unpleasant natural, economical or even political incidents where mangers need to handle them, properly. This paper presents an empirical survey to investigate on an electromotor maker when it faces different chaos. The proposed study uses balanced scorecard in terms of four different perspectives including internal process, learning and growth, customer and financial performances. For each perspective, the proposed study uses analytical hierarchy process to rank different sub-criteria. Based on the results of our survey profit margin is the most important item followed by profit capability and brand name while productivity and sales force performance were the least important items.
\end{abstract}

(c) 2013 Growing Science Ltd. All rights reserved.

\section{Introduction}

Managing an organization under chaos and uncertainty is often a concern of academic society. These days, we may face unpleasant natural, economical or even political incidents where mangers need to handle them, properly. In order to overcome any external challenges threatening business units, we need to study the structure of an organization based on a reliable method such as balanced scorecard (BSC), carefully (Huang et al., 2011). BSC is one of the most popular approaches for measuring the performance of business units in terms of four perspectives including internal process, learning and growth, customer and financial figures. BSC was originally developed by Kaplan and Norton (Kaplan \& Norton, 1996, 2000, 2002, 2004) and it has become a popular method for the past two decades. Mozaffari et al. (2012), for instance, performed BSC to measure the performance of an Islamic Azad University using fuzzy numbers for handling the existing uncertainty on the numbers. 
Kohneh et al. (2013) implemented a combination of analytical hierarchy process (AHP) and BSC to measure the performance of five civil registry offices in Tehran, Iran by using fuzzy terms to handle uncertainty associated with input numbers. They reported that learning and development was number one priority with relative importance of 0.491 , followed by customer with relative importance of 0.293 , internal process with relative importance of 0.173 and financial affairs comes at last with relative weight of 0.043 .

Danaei and Hosseini (2013) studied the existing strategic objectives in the strategy map of a pipe company located in city of Shiraz, Iran and reported that the firm could reach $41.4 \%$ of its financial objectives, $87.38 \%$ of its customers' requirements, $66.13 \%$ of internal processes and $70.94 \%$ of its learning necessities according to four major BSC requirements. Nemati et al. (2013) presented a technique to learn the effect of knowledge management (KM) practices on organizational performance. They implemented BSC to materialize this comprehensiveness. They reported that KM practices could influence on the overall performance.

Mozaffari et al. (2013) in a comprehensive investigation measured the performance of Islamic Azad University of Semnan by the utilization of strategy map as a prominent part of BSC. Darvish et al. (2012) performed an investigation on the effect of human resource competencies on productivity by considering different issues such as different competencies associated with human resources, how it was possible to persuade and strengthen such competencies in organizations and whether human resource competencies could impact organizational productivity or not. They reported that human resource competency could influence organizational productivity. Besides, all dimensions of human resource competencies had significant impact on organizational productivity.

Ghotbuee et al. (2012) performed an empirical investigation to measure the relative efficiency of seven health care centers in province of Semnan, Iran, which were under the coverage of social security organization of Iran. They implemented a hybrid of balanced score card and data envelopment analysis to measure the performance of the organization based on BSC method. The preliminary results showed that all seven units perform relatively well and the overall efficiency of all units in this province is 0.769 .

Analytical hierarchy process (AHP) is one of the most popular multi criteria decision making techniques for ranking difference alternatives (Saaty, 1980). According to Abdolshah et al. (2012), in an environment, which is highly competitive and everything changes very quickly, managers of organizations encounter with problems such as how to identify important factors preventing firms from optimum implementation of available resources and capacities and invest more on key factors. To reach this goal, management of different firms need to develop an effective strategy map for their organizations. The strategy map is a constructional and expanding method to detect relationships among all components of organizations. Abdolshah et al. (2012) used strategic objectives in the strategy map of one of the best producer of electric auto part makers in Iran, Electric Vehicle Co. East, investigated the firm based on BSC method and assigned appropriate values to important factors based on AHP technique with Fuzzy logic (Grigoroudis et al., 2012).

\section{The proposed method}

This paper presents an empirical survey to investigate an electromotor maker when it faces different chaos. The proposed study uses balanced scorecard in terms of four different perspectives including internal process, learning and growth, customer and financial performances. For each perspective, the proposed study uses AHP method to rank different sub-criteria. The proposed study of this paper uses Delphi technique to find important factors and after some brain storming discussions we have reached some factors summarized in Table 1. As we can observe, for each perspective, we have determined four sub-criteria. 
Table 1

The summary of important factors in terms of BSC perspectives

\begin{tabular}{cll}
\hline Perspective & Criteria & Objectives \\
\hline \multirow{2}{*}{$\begin{array}{c}\text { Financial } \\
\text { figures }\end{array}$} & Profit capability & Increase and continuous improvement on investment \\
& Profit margin & Increase and continuous improvement on investment \\
& Increase in income & Increase in profit making investment \\
\cline { 2 - 3 } $\begin{array}{c}\text { Customer } \\
\text { perspective }\end{array}$ & Return on equity & Productivity improvement \\
& Brand & Increase in customer satisfaction \\
& Market share & Cooperation with well known brands \\
& On time delivery & Increase in market share \\
\hline \multirow{2}{*}{$\begin{array}{c}\text { Internal } \\
\text { processes }\end{array}$} & Sales performance & Increase in customer loyalty \\
& Quality & Improvement in sales performance \\
& Product development & Improvement in quality of products \\
\cline { 2 - 3 } & Productivity improvement & Improvement in different services \\
\hline \multirow{2}{*}{$\begin{array}{c}\text { Learning } \\
\text { growth }\end{array}$} & Structure of employee & Improvement in delivering products or services \\
\cline { 2 - 3 } & Education per employee & Improvement in employee structure \\
& Employee satisfaction & Increase on short term educational programs \\
& Appropriate job positions & Improvement in productivity \\
\hline
\end{tabular}

\section{The results}

As explained earlier, we have used AHP method to rank different perspectives of BSC factors and these rankings are summarized in Fig. 1 as follows,

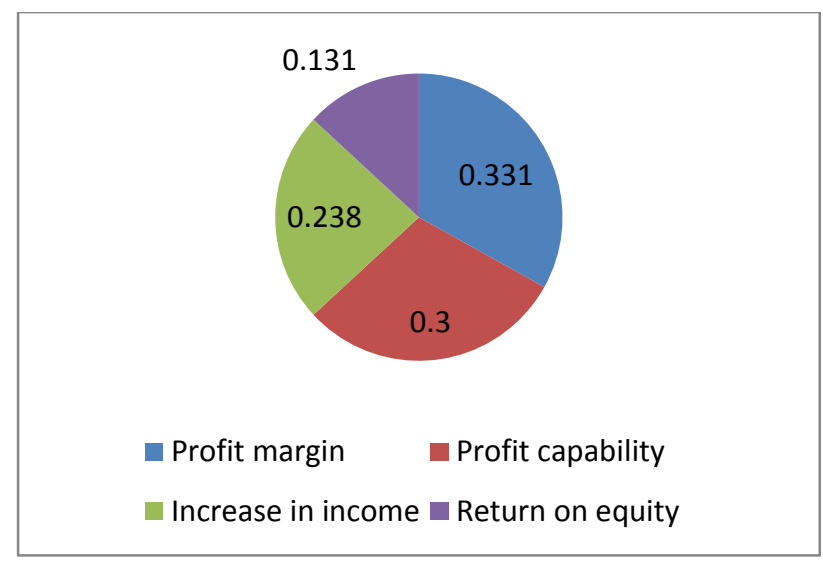

Fig. 1. The summary of ranking for financial perspectives

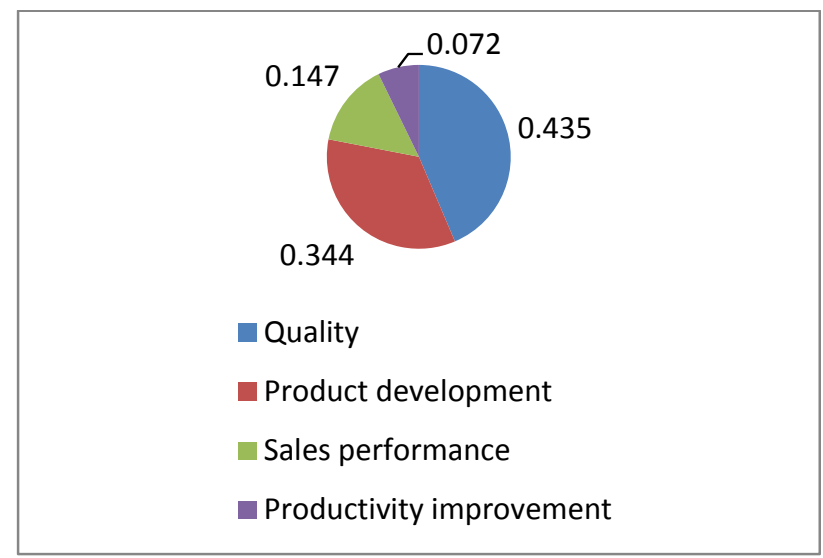

Fig. 3. The summary of ranking for internal processes

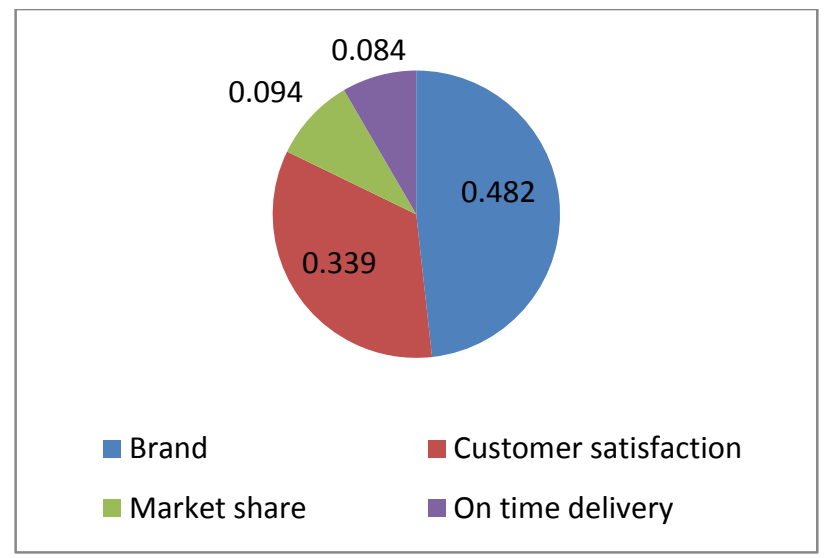

Fig. 2. The summary of ranking for customer perspectives

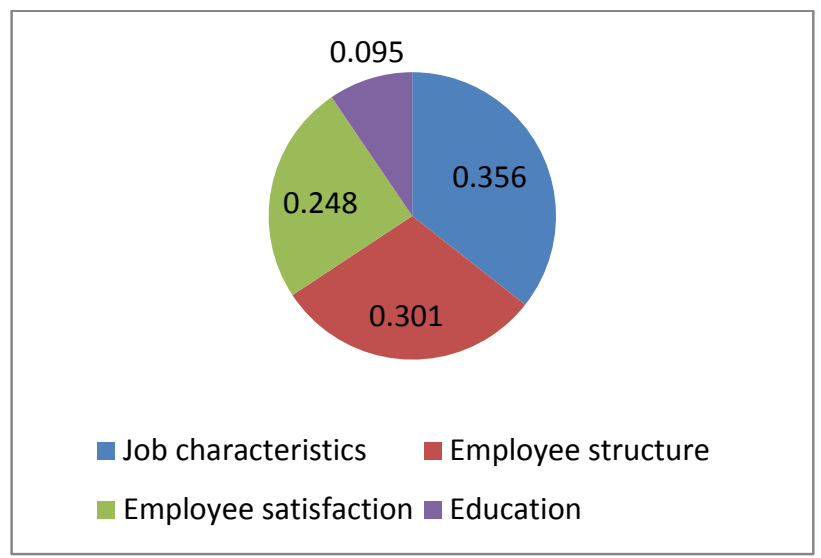

Fig. 4. The summary of ranking for learning and growth 
We have also compared all four major perspectives and the results for financial, customer, internal and learning \& growth were $0.446,0.335,0.068$ and 0.131 , respectively. Finally, we have calculated the overall performance of all 16 components and Fig. 5 summarizes the results of our survey,

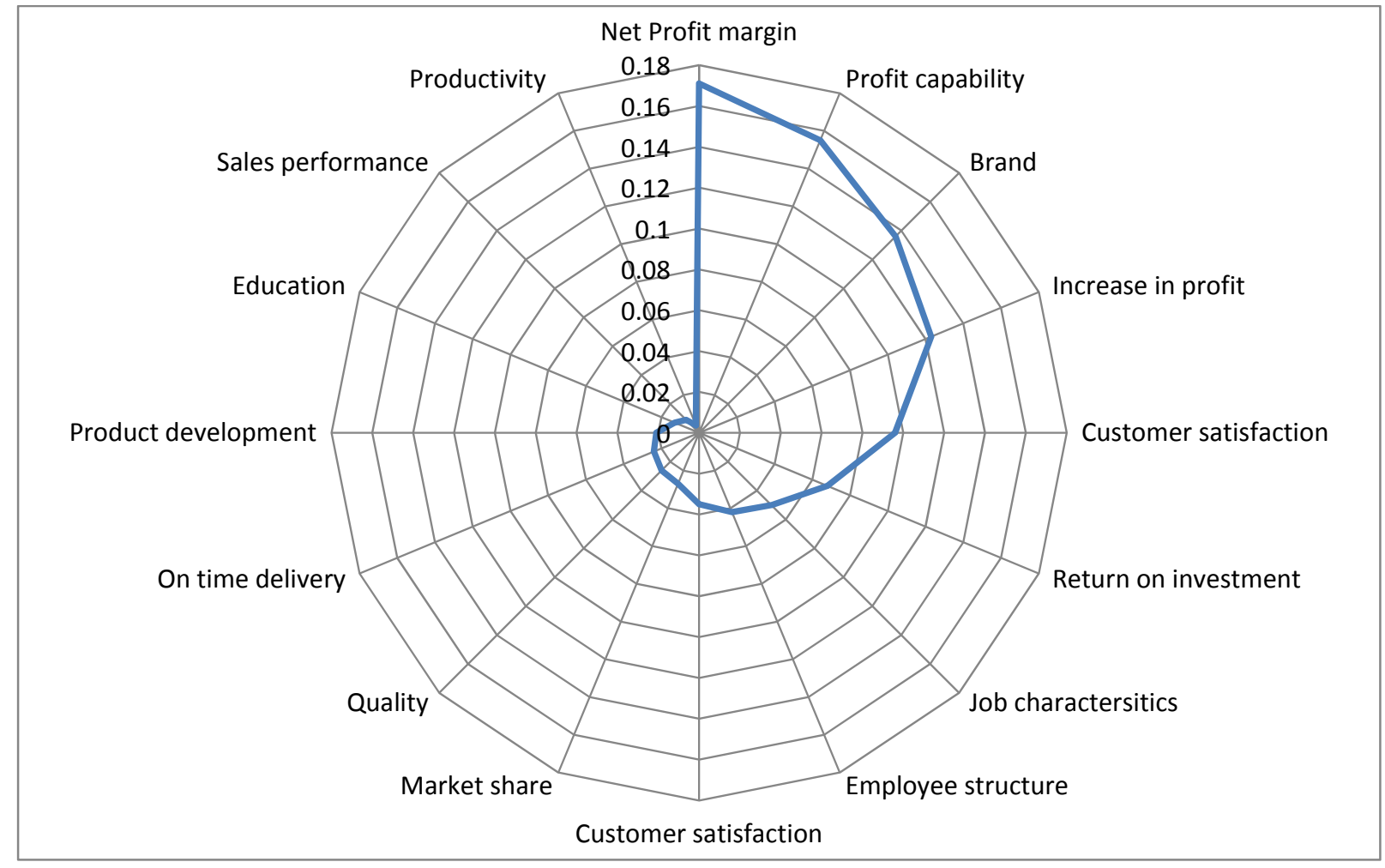

Fig. 5. The summary of the ranking of different BSC factors

Based on the results of our survey profit margin has been the most important item followed by profit capability and brand name while productivity and sales force performance were the least important items. In other words, our experts believe in order to handle any unwanted chaos due to natural, economical or even political problems, the proposed case study has to concentrate on net profit margin. This could be accomplished by reducing the costs of raw materials, improvement on reducing waste materials, increase in production in an attempt to reduce fixed cost components and change fixed cost components into variable items. In fact, when most portions of firms' related costs components are converted into variable costs, it will be easier to handle any trouble making chaos in short term.

Note that this study was accomplished during the year 2012 where local currency was devaluated significantly and the proposed firm of this study was in great pressure since the raw materials were getting expensive and the firm was faced with shortage in liquidity. In such circumstances, banks were unwilling to open line of credit or give loans to industries. Many people attempt to convert their local currency to other foreign currencies in an attempt to get rid of short-term challenges. Our decision makers believe we must concentrate on products with higher profit margin just to make sure we could absorb more liquidity.

\section{Conclusion}

In this paper, we have presented an empirical investigation on measuring the relative importance of various factors influencing performance of a firm based on the implementation of balanced scorecard. The proposed study of this paper tried to choose important factors during the chaos events specially 
the recent political crises. Based on the results of our survey profit margin has been the most important item followed by profit capability and brand name while productivity and sales force performance were the least important items. In other words, our experts believe in order to handle any unwanted chaos due to natural, economical or even political problems, the proposed case study has to concentrate on net profit margin. This could be accomplished by reducing the costs of raw materials, improvement on reducing waste materials, increase in production in an attempt to reduce fixed cost components and change fixed cost components into variable items.

\section{Acknowledgment}

The authors would like to thank the officials of the electromotor builder for cordially cooperating with our team in accomplishment of this survey.

\section{References}

Abdolshah, M., Javadinia, M., Astanbous, M \& Eslami, M. (2002). An integrated approach to analyze strategy map using BSC - FUZZY AHP: A case study of auto industry. Management Science Letters , 2(2), 705-712.

Danaei, A \& Hosseini, A. (2013). Performance measurement using balanced scorecard: A case study of pipe industry. Management Science Letters, 3(5), 1433-1438.

Darvish, H., Moogali, A., Moosavi, M \& panahi, B. (2012). An empirical study on human resource competencies and its relationship with productivity. Management Science Letters, 2(7), 26152624.

Ghotbuee, A., Hemati, M \& Fateminezhad, R. (2012). An empirical study based on BSC-DEA to measure the relative efficiencies of different health care centers in province of Semnan, Iran. Management Science Letters , 2(7), 2643-2650.

Grigoroudis, E., Orfanoudaki, E., \& Zopounidis, C. (2012). Strategic performance measurement in a healthcare organization: A multiple criteria approach based on balanced score. Omega, 40, 104119.

Huang, H. C., Lai, M.C., \& Lin, L. H. (2011). Developing strategic measurement and improvement for the biopharmaceutical firm: Using the BSC hierarchy. Expert Systems with Applications, 38, 4875-4881.

Kaplan, R.S., \& Norton, D.P. (1996). Using the balanced scorecard as a strategic management system. Harvard Bus. Review (January.February). 74(1), 75-85.

Kaplan, R.S., \& Norton, D.P. (2000). The strategy-focused organization: How balanced scorecard companies thrive in the new business environment. Harvard Bus. School Press.

Kaplan, R.S., \& Norton, D.P. (2002). Building the Balanced Scorecard in Public Sector. Balanced Scorecard Report from Interview with Rick Pagsibigan, September 19.

Kaplan, R.S., \& Norton, D.P. (2004). Strategy maps: Converting intangible assets into tangible outcomes. Boston, MD: Harvard Bus. School Press.

Kohneh, A., Yazdani, B \& Kamalian, A. (2013). Performance measurement in governmental agencies using BSC-AHP: A case study of Civil Registry Office in Tehran. Management Science Letters, 3(4), 1255-1260.

Mozaffari, A., Karkehabadi, H., Kheyrkhahan, M \& Karami, M. (2012). A development in balanced scorecard by designing a fuzzy and nonlinear Algorithm (case study: Islamic Azad university of Semnan). Management Science Letters, 2(5), 1819-1838.

Mozaffari, A., Kalaei, H., Shahhosseini, M \& Chaghouee, Y. (2013). A new framework for performance evaluation system using strategy map: A case study of Islamic Azad University of Semnan. Management Science Letters , 3(4), 1041-1048. 
1654

Nemati, B., Ghaemi, V \& Rashidi, M. (2013). The Effect of KM implementation on organizational performance with balanced scorecard methodology. Management Science Letters, 3(3), 10251036.

Saaty, T. L. (1980). The Analytic Hierarchy Process. New York: McGraw-Hill. 